\title{
Effect of Antimicrobial Peptides and Chemicals Produced by Animals on Aspergillus fumigatus
}

\author{
AlBaraa Akram, Glen McCann \\ Department of Pharmaceutical Biotechnology, De Montfort University, Leicester, UK \\ Email: albraaakram94@gmail.com
}

How to cite this paper: AlBaraa Akram and McCann, G. (2021) Effect of Antimicrobial Peptides and Chemicals Produced by Animals on Aspergillus fumigatus. Advances in Bioscience and Biotechnology, 12, 173-192.

https://doi.org/10.4236/abb.2021.126012

Received: May 11, 2021

Accepted: June 27, 2021

Published: June 30, 2021

Copyright $\odot 2021$ by author(s) and Scientific Research Publishing Inc. This work is licensed under the Creative Commons Attribution International License (CC BY 4.0).

http://creativecommons.org/licenses/by/4.0/

\begin{abstract}
The problem of multidrug-resistant pathogens as bacteria, fungi and yeast in addition to the restriction of using antibiotics as growth promoting substances in food has attracted the attention to looking for alternative sources instead of conventional antibiotics like natural products which have antimicrobial activity. Much interests and researches have been focused on using natural antimicrobial peptides and chemicals extracted from animal secretions and some insect's venoms as they exhibit antimicrobial activity against pathogens with lower resistance and higher synergistic effects if they were given in combination with blends of them. In this paper, some antimicrobial chemicals extracted from giraffes are shown in addition to their activity against Aspergillus fumigatus species using optical density analysis technique then their Minimum Inhibitory Concentrations (MIC) will be determined as well as ICs 50 to measure the potency to inhibit a biological function using programmes like Gene5, graph pad prism as well as testing antimicrobial activity of some chemicals which are provided in animal secretions.
\end{abstract}

\section{Keywords}

Antimicrobials, Aspergillus fumigatus, Antimicrobial Peptides

\section{Introduction}

\subsection{Antimicrobial Peptides and Proteins}

It is notable that antimicrobial peptides particularly cationic ones play a significant role within the natural immunity of animal defences against topical and general microbes altogether species of life. These antimicrobial peptides may be evoked or expressed by bacterium, fungi or yeast, most peptides are smart with wide strains of microorganisms as well as antimicrobial strain like Methicillin 
Resistant Staph Aureus (MRSA) and Vancomycin Resistant Staph Aureus (VRSA).

A number of them are synergistic with standard antibiotics as they need potent activity of the many microorganism secretions like lipopolysaccharides (LPS) and lipoteichoic acid that free by many bacterial strains and cause fatal infections. In distinction with antibiotics, the peptides have a plus that they forestall protein induction by bacterium in tissue culture and human blood as peptides do that by block LPS interaction with the blood serum macromolecule of the host. Ion antimicrobial peptides are evoked by lipopolysaccharides and are ready to dampen the septic response of animal host cells to lipopolysaccharides [1].

Animals are exposed to legion pathogens daily by intake, inhalation and call and their natural immunity plays a significant role in their resistance to infection. The role of antimicrobial peptides has been magnified apparently [2], and there's a promising proof has been discovered from decades reports that their antimicrobial action is necessary because the host protein, immune cells and phagocytes.

Microbial infections evoked by microorganism lipopolysaccharides by a regular pathway just like pathway employed by mammalian immune system [3].

\section{Examples of Species Secrete Antimicrobial Peptides}

Most species produce antimicrobial peptides as well as antimicrobial peptides made by bacterium, fungi, hydra, insects like bee produces mastoparan, melittin, poneratoxin, moricin, ceropin et al. [4], frogs turn out dermaseptin and magainin [5], craniate turn out defensins and cathelicidin [6] and even mammals produce conjointly defensins, cathelicidin and protegrin. ion amide is meant from C-terminal domain of human blood platelet atomic number 20 [7] and today, the foremost wide used antimicrobial amide is nisin that is thus far the sole Food and Drug Administration approved antimicrobial peptide and it's used as a synthetic preservative [8].

\subsection{Antimicrobial Chemicals}

Animals always use metabolites made by dependent bacterium for defence against microorganisms like bacteria, parasites and alternative pathogens. Secretion from the sweat and oily glands from some animals like giraffes and deer and secretion from preen glands of birds are used for this purpose though these chemicals are employed by the bird apparently.

\section{Examples of Species Turn out Antimicrobial Chemicals}

Most animals like mammals, fish, reptilian and birds turn out antimicrobial chemicals as a psychoanalytic process against microorganisms as an example, chicken eggs have defence mechanisms which can have several potentialities for victimisation for the sake of protection of human and animal health.

The chicken egg is an efficient supply of nutrients like metallic element and metal. The chemical, physical and defence mechanisms of egg guarantees pro- 
tection of the embryo against invasion infection and multiplication of being. Physically, the egg shell and therefore the shell membrane of the egg forestall microbial penetration to the egg wall. Chemically, the $\mathrm{pH}$ scale and consistency forestall microbial proliferation and multiplication. Biologically, the albumen contains varied proteins that have antimicrobial activities as microorganism cell lysis, sustenance binding and metal binding that are forms of natural and innate psychoanalytic process of the egg itself. Varied biological functions of the egg compositions as well as immunomodulating activity, antimicrobial activity and inhibition of peptidase might all reinforce the importance of those substances in hindrance and protection of animal and human against diseases [9].

Another example is hoopoe preen that secretes antimicrobial chemicals which were tested by suggests that of antibiotic injections to check if the dependent bacterium resides inside the oil gland are liable for their production as this bird produces 2 forms of chemical secretions disagree in chemical composition. One in every of them contains mixture of volatile substances whereas the opposite one doesn't contain these volatile substances. All volatile chemicals are detected robust bactericide properties and mixtures of those chemicals at totally different concentrations stifled the expansion of some bacterial strains that have been assayed by different ways.

It has been supposed that these chemicals have a job within the antimicrobial activity that the presence of that dependent bacterium in the uropygial glands of this animal contains a solid relationship to its antimicrobial activity which might be employed in topical medicines. There was recording obtained from gas chromatography/mass spectroscopy analysis shown in Figure 3 showing peaks at short extraction times but twenty-one minutes consistent with volatile substances [10] (Figure 1).

Alternative example, the glands and hair of giraffes contain several varied bactericide chemicals like indole, alkyl group indole or skatole and phenol. There mixture and combination turn out synergistic result quite victimisation all one by one which might be used for defence against being as phenol is employed wide for preservation of internal secretion (Figure 2).

The Giraffe produces these chemicals which might be detected by totally different ways, methylene chloride or DMSO of hair samples of male and female Giraffes were analysed by gas chromatography/mass spectroscopy that produces 2 chemicals which are indole and 3-methyl indole which are powerfully accountable to the robust scent of the giraffe, alternative chemical extracts are p-cresol, heptanal, octanal, nonanal, benzaldehyde, octane, hexadecenoic acid and tetra-decanoic acid (Figure 3).

Indole is soluble in hot water $0.19 \mathrm{~g} / 100 \mathrm{ml}$ in 20 Celsius degrees, methyl indole or skatole is soluble in water $21 \mathrm{~g} / 100 \mathrm{ml}$ in 20 Celsius degrees and finally $\mathrm{p}$-cresol is soluble in water according to the temperature $2.4 \mathrm{~g} / 100 \mathrm{ml}$ at $40 \mathrm{Cel}-$ sius degrees and $5.3 \mathrm{~g} / 100 \mathrm{ml}$ at 100 Celsius degrees. It is also soluble in methanol and diethyl ether and fully miscible in both of them. These three compounds are easily extracted using DMSO. 

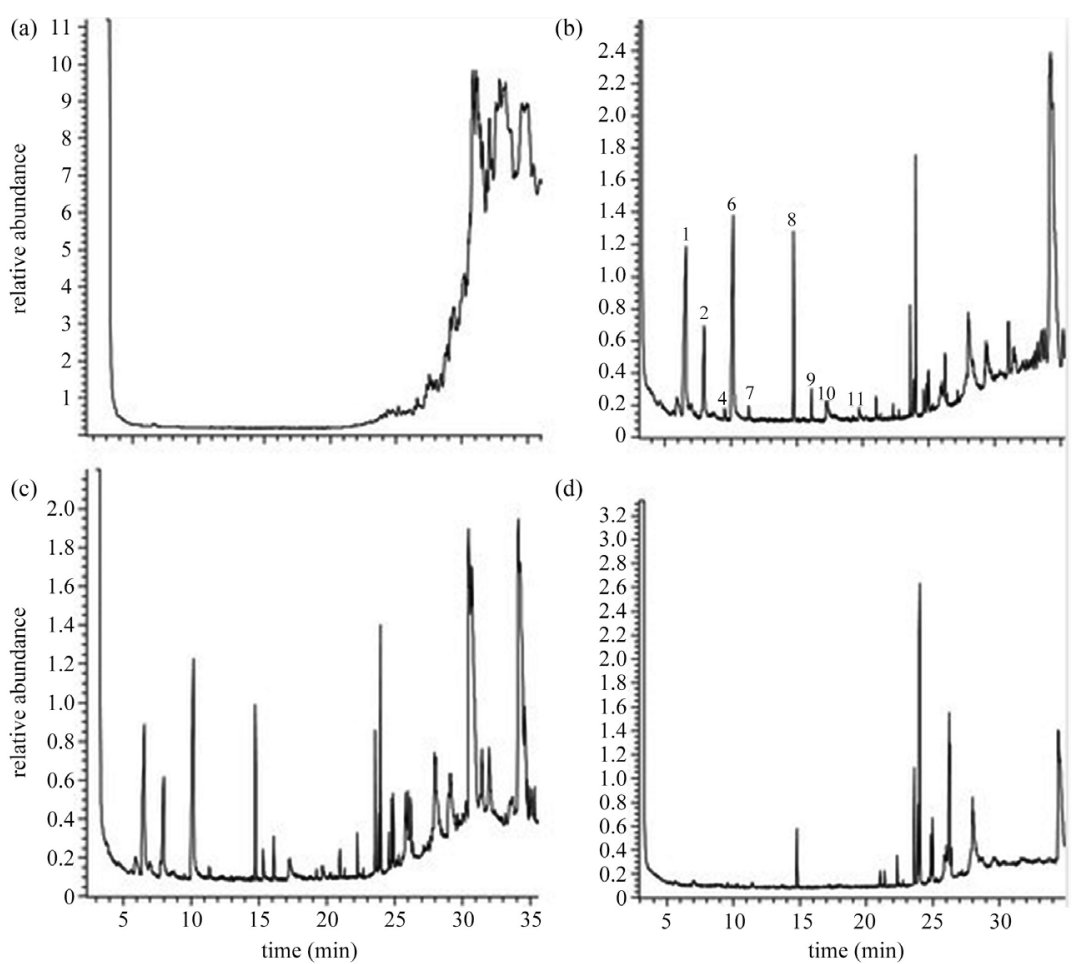

Figure 1. Recording of hoopoe preens secretions. (a) represents the white preens secretion of the non-breeding adults. (b) and (d) represent dark secretion in three nesting hoopoes of constant brood when six days of treatment with (b) solely manipulation, while not injection, (c) saline water injected inside the oil gland lobes and (d) amoxycillin injected within the uropygial gland lobes. Peaks are numbered consistent with the list of compounds within the descriptive analysis.

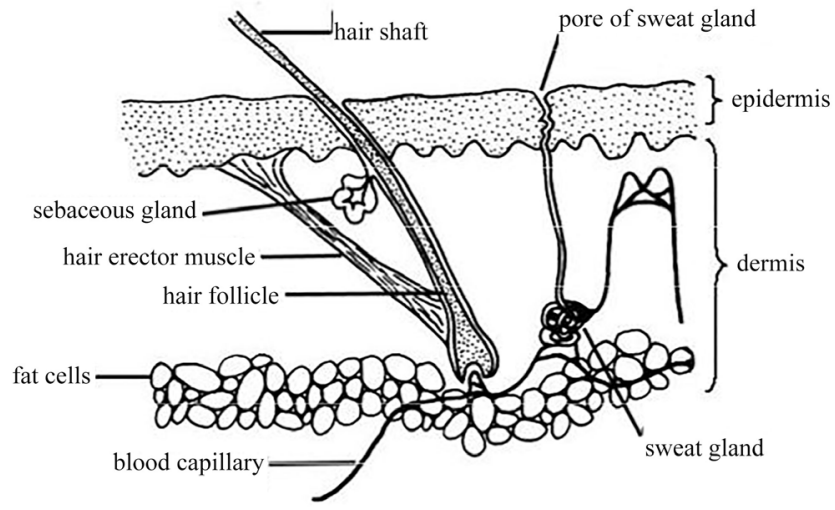

Figure 2. The anatomy of giraffes' skin showing deep and superficial dermis with sweat, sebaceous glands and hair.<smiles>c1ccc2[nH]ccc2c1</smiles><smiles>Cc1c[nH]c2ccccc12</smiles><smiles>Cc1ccc(O)cc1</smiles>

Figure 3. The chemical structure of main chemicals of giraffes' hair indole, skatole and p-cresol. 
These compounds will defeat microorganisms and ectoparasitic arthropods, most of those compounds are fungistatic and biological process which implies that they inhibit multiplication of bacterium and fungi in order that they might act with disinfectant standard antibiotics like antibiotic and cephalosporins as they show therapeutic result against class skin pathogens and alternative microorganisms, the amount of p-cresol in Giraffe is enough to repel any being [11] in order that is why hunters and naturalists connected between these chemicals and therefore the robust scent of the giraffes [12] thus giraffes may be detected whereas standing quite 250 meters from hunters and dangerous animals like lions and tigers [13] some finds this odour is pleasant and engaging however on the opposite facet some researchers see it's not pleasant [14] [15]. It had been instructed that Giraffe scent repels lions and alternative predators however there aren't any tests or any functions are reportable.

It had been reportable that analysis of hair and alternative dermal material of the Giraffe indicating presence of diverse chemical volatile compounds, indole and skatole are extremely odoriferous to humans and it had been reportable that they need biological process and fungistatic activity against wide selection of microbes that may be exist on the skins in order that they may be used for antimicrobial topical preparations and antimicrobial patches which might be absorbed by skin.

Table 1 shows the full particle current of some chemicals.

The opposite two alkaloids, indole and 3-methyl indole or skatole are the most accountable to the dangerous odour of Giraffe as they're just like the natural odour. Indole is found naturally in Jasmin, genus Vinca and orange blossom, alkyl group indole and indole have a soiled odour in high concentration however it's acceptable after they are diluted that they will be used for fragrance manufactures [16] but neither of those chemicals are detected in giraffes.

There is sexual dimorphism in the content of indole, methyl indole and para cresol as males have more than females in quantities of these chemicals by $54 \%$, $69 \%$ and $46 \%$ respectively.

These compounds have antimicrobial activity, Trichophyte that could be a zoophilic flora found on the skin of animals and athlete's foot which liable for human skin infection may be stifled by indole [17], nonanal [18], characid saturated fatty acid and hexadecenoic acid [19].

The expansion of skin bacterium may be avoided by a number of Giraffe derived compound. as an example, Staph aureus is stifled by indole, benzaldehyde [20], octanal [21], p-cresol, characid saturated fatty acid [22], hexadecenoic acid and nonanal [23] these compounds may be used against penicillin resistant Staphylococci aureus (MRSA).

Mostly, the activity of these compounds is moderate however acting synergistically will build their activity more impregnable as indole has synergistic result with some chemicals to inhibit growth of caries caused by eubacteria bacterium as its addition to caryophyllene as an example can cut back minimum restrictive concentration (MIC) from $1600 \mu \mathrm{g} / \mathrm{ml}$ to six. $25 \mu \mathrm{g} / \mathrm{ml}$. 
Table 1. The main volatile compounds detected from the skin of the giraffes, values are portrayed by percentages of the full particle current (\%TIC), (a) represents minor compounds with share but a $2 \%$ of TIC that cannot be known.

\begin{tabular}{ccc}
\hline Compound & Male (\%TIC) & Female (\%TIC) \\
\hline Octane & 5.6 & 6.9 \\
Benzaldehyde & 3.7 & 5.7 \\
Heptanal & 5.3 & 2.3 \\
Octanal & 2.9 & 3.6 \\
Nonanal & 22.5 & 28.9 \\
p-Cresol & 5.5 & 3.0 \\
Indole & 6.5 & 3.0 \\
3-Methylindole & 14.0 & 4.7 \\
Tetradecanoic acid & 8.1 & 11.4 \\
Hexadecanoic acid & 11.9 & 11.3 \\
3,5-Androstadien-17-one & 8.1 & 6.9 \\
Minor compoundsa & 6.0 & 12.5 \\
\hline
\end{tabular}

Aspergillus fumigatus is a fungus which causes invasive fungal infection, chronic pulmonary infections and allergic bronchopulmonary Aspergillosis, it affects also immunodeficient patients who suffer from AIDS and patients who are taking immunosuppressants as well as neoplastic diseases for organ transplantations. It is killed mainly by azole chemicals as indole and methyl indole and it is grown on SABS [24].

Therapeutic applications of animal secretions:

Animal peptides and chemicals are broad spectrum antimicrobial agents that have disinfectant and static activities against gram positive, gram negative, protozoa and fungi.

Thanks to their property, broad spectrum, simple chemical synthesis and low likelihood microorganism resistance, they're developed as therapeutic agents for humans [25]. Animals are in battle with microorganisms which is why animals' construction is meant naturally to defeat microbes thus peptides are used naturally by animals to defeat microorganisms.

Antibiotics are used for variant totally different settings physiologically and pathologically, the somatic cell cells of animals contain antibiotic peptides inside granules intracellularly, providing cells non-oxidative a natural disinfectant capability [26]. The epithelia of sure vertebrate animals and insects specific several antimicrobial peptides, protective the animal tissue surface against microbial penetration thus it's a natural mechanical and biological barrier [27]-[33].

In some animals e.g., arthropod, the haemocyte that could be a current cell accountable to blood coagulation in class blood platelet, aggregates at the position of the wound cathartic antimicrobial agents and physiological systems that 
they're expressed in giant half represent the division of host animal weapons system which referred to as natural immunity.

The study of those antimicrobial animal secretions was concerned from totally different animal species as well as frogs, mammals and even sharks. each basic studies of those categories of antimicrobials and their biological systems in addition as apply them for human therapeutic application are concerned as sprays, patches, socks for leg ulceration to diabetic patients. Animal derived antimicrobial peptides and chemicals may be used for plants to repel and kill pests and insects.

\section{Materials and Methods}

\subsection{Chemicals}

\section{Overview of MIC Testing}

To summarise minimum inhibitory concentration test, a culture of pure microorganisms had been grown in the appropriate broth. the culture had been standardized using recognized standard microbiological techniques to obtain concentration equals nearly 1 million cells/ml. the more standardized microbiological culture the more reproducible obtained test results.

The antimicrobial substance frequently had been diluted, usually 1:1 using the appropriate diluent. After dilution of the antimicrobial, volume of the standard volume equals the volume of diluted antimicrobial had been added for each dilution vessel until reaching the microbial concentration nearly to $500,000 \mathrm{cells} / \mathrm{ml}$.

Incubate the serial diluted antimicrobial substance at the proper temperature according to the type of the microorganism for the right duration which is between 18 to 24 hours, the longer incubation duration, the more reproducible results obtained.

Observe the serial diluted vessels after incubation to screen microbial growth which can be detected by turbidity or pellet formation in the bottom of vessel, the last diluted vessel which that had not demonstrated growth, turbidity or pellet formation determines the minimum inhibitory concentration of the antimicrobial agent.

\section{Advantages of MIC:}

- Easy to prepare and straightforward which permits reproducibility.

- Can be done on a very small scale without needing to use high amounts of the antimicrobial agent which is very important for antimicrobial agents used experimentally e.g. antimicrobial peptides which are synthesized biologically.

\section{Disadvantages of MIC:}

- The variations of parameters of MIC test can affect the apparent results of MIC. For example, the long incubation will show higher MIC and lower inoculum concentration can result apparent lower MIC.

- In bacteriostatic antimicrobial agent, some microorganisms will stop growing but not killed, there can be still the same number of cells waiting until the antimicrobial agent is neutralized. 


\subsection{Microbiology Culture Preparation}

It depends mainly on culturing Aspergellus fumigatus in its proper culture media and incubation in the proper temperature. You need sabouraud culture medium and distilled water with an empty bottle, scale and spatula.

Prepare amount per $500 \mathrm{ml}$ of water and to prepare Incubate this bottle of sabouraud culture medium overnight in the autoclave in 121 Celsius degrees.

A fungus including Aspergillus fumigatus is grown in sabouraud culture medium.

Prepare 10 tubes for this media then fill each with $10 \mathrm{ml}$ of the culture and bring Petri dishes containing each individual microorganism.

Prepare culture media for fungi by the following:

Label each bottle with the name of the culture media and the intended microorganism (Asp. fumigatus).

Take a wire loop and place the wire loop in the flame of the Bunsen burner until glowing red along its length for sterilization then leave the loop to cool down.

Petri dish had been picked up and open the lid had been opened to make a streak then the lid of the tube had been opened of the appropriate culture media and loop had been dipped into the bottle.

These steps had been repeated for each tube then incubated overnight each one in the right temperature.

The culture had been diluted by adjusting the ratios between bacterial culture and broth (Table 2).

\subsection{Optical Density Analysis}

In a clean tube the solvent only is put just to tare the device then from $10 \mathrm{ml}$ of the tube aseptically $1 / 20$ culture had been prepared to solvent by insertion $50 \mu \mathrm{l}$ of culture against $950 \mu \mathrm{l}$ T.E buffer (tris and EDTA) and they had been measured at wave length $600 \mathrm{~nm}$ then cultures had been diluted to 0.5 in absorbance 0.063 e.g. if $6.3 \mathrm{O}$. D $500 \mu \mathrm{l} 49.5 \mathrm{ml}=1 / 100$. The resulted value had been multiplied in 20 to obtain the final optical density.

If optical density is so high, $1 / 40$ ratio could have been prepared which had been represented by $25 \mu \mathrm{l}$ of culture mixed with $975 \mu \mathrm{l}$ of T.E.

\subsection{Chemicals Preparation}

Using DMSO as a solvent extract indole, methyl indole (skatole) and p-cresol four of 24 well plates had been prepared for each individual microorganism and had been divided as follows (Table 3, Table 4).

Table 2. Dilution culture of microorganisms shows the ratios and amounts of culture media and broth in $\mathrm{ml}$.

\begin{tabular}{lccc}
\hline Name of M.O & Ratio & Culture $(\mathrm{ml})$ & Broth $(\mathrm{ml})$ \\
\hline Asp. Fumigatus & $1: 1$ & 10 & \\
\hline
\end{tabular}


Table 3. Scheme shows the content of the 24 well plates according to their contents and concentrations of broth, cells and chemical 1 refers to $20 \mathrm{mM}, 2$ refers to $10 \mathrm{mM}, 3$ refers to $5 \mathrm{mM}, 4$ refers to $1 \mathrm{mM}, 5$ refers to $500 \mu \mathrm{M}, 6$ refers to $250 \mu \mathrm{M}, 7$ refers to $25 \mu \mathrm{M}, 8$ refers to $12.5 \mu \mathrm{M}, 9$ represents positive control contains cells without chemicals and 10 represents negative control doesn't contain any cells or chemicals but contains just media.

\begin{tabular}{ccccccc}
\hline & 1 & 2 & 3 & 4 & 5 & 6 \\
\hline A & 1 & 2 & 3 & 4 & 5 & 6 \\
B & 1 & 2 & 3 & 4 & 5 & 6 \\
C & 7 & 8 & $9(+)$ & $10(-)$ & Empty & Empty \\
D & 7 & 8 & $9(+)$ & $10(-)$ & Empty & Empty \\
\hline
\end{tabular}

Table 4. The ratios and concentrations of media and cells required in each well according to Figure 3 before adding chemical.

\begin{tabular}{cccc}
\hline Code & Well number & Ratios & Concentrations \\
\hline 1 & A1 and B1 & 1 & $20 \mathrm{mM}$ \\
2 & A2 and B2 & $1 / 2$ & $10 \mathrm{mM}$ \\
3 & A3 and B3 & $1 / 2$ & $5 \mathrm{mM}$ \\
4 & A4 and B4 & $1 / 5$ & $1 \mathrm{mM}$ \\
5 & A5 and B5 & $1 / 2$ & $500 \mu \mathrm{M}$ \\
6 & A6 and B6 & $1 / 2$ & $250 \mu \mathrm{M}$ \\
7 & C1 and D1 & $1 / 10$ & $25 \mu \mathrm{M}$ \\
8 & C2 and D2 & $1 / 2$ & $12.5 \mu \mathrm{M}$ \\
9 & C3 and D3 & Positive control & just Cells \\
10 & C4 and D4 & Negative control & No cells \\
Empty & C5 and D5 & Empty & Empty \\
Empty & C6 and D6 & Empty & Empty \\
\hline
\end{tabular}

In the First plate put $20 \mu \mathrm{M}$ of indole to $500 \mu \mathrm{M}$ of the cells and media in all wells except the last eight wells, put the cells only without chemicals in two wells as a positive control and in another two wells put the media only as a negative control.

In the Second plate $20 \mu \mathrm{M}$ of skatole was placed to $500 \mu \mathrm{M}$ of the cells and media in all wells except the last eight wells, put the cells only without chemicals in two wells as a positive control and in another two wells put the media only as a negative control.

In the Third plate put $20 \mu \mathrm{M}$ of p-cresol to $500 \mu \mathrm{M}$ of the cells and media in all wells except the last eight wells, put the cells only without chemicals in two wells as a positive control and in another two wells put the media only as a negative control. 
In the Fourth plate put $20 \mu \mathrm{M}$ of blend of indole, cresol and skatole to $500 \mu \mathrm{M}$ of the cells and media in all wells except the last eight wells, put the cells only without chemicals in two wells as a positive control and in another two wells put the media only as a negative.

Repeat this process for each plate with changing microorganisms used by making four plates for each microorganism each individual one contains indole, methyl indole (skatole), p-cresol and blend then label each plate according to the type of cells, media, chemical used control according to Table 3 then incubate them overnight (Figure 4, Table 5).

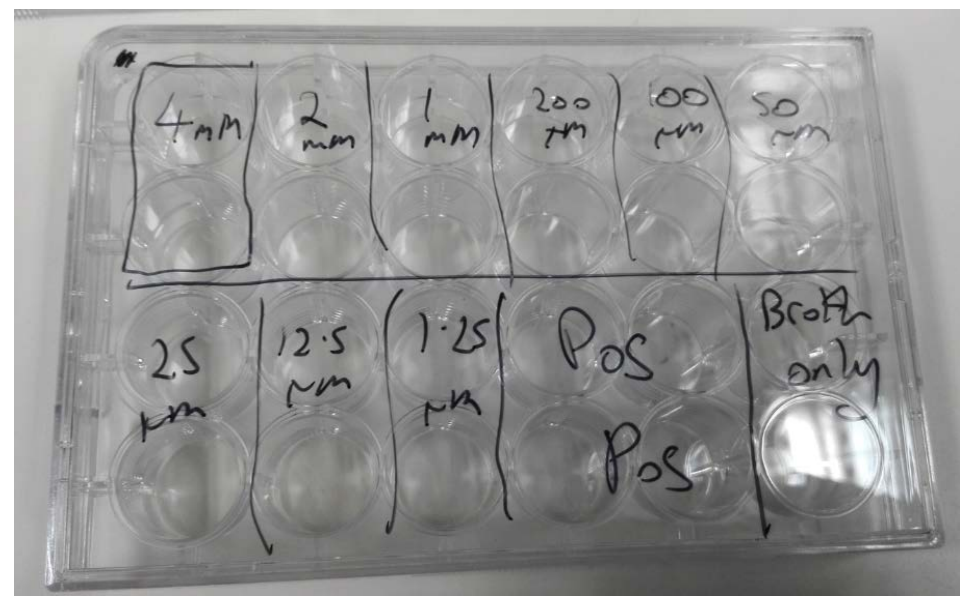

Figure 4. Scheme shows the content of the 24 well plates according to their contents and concentrations of broth, cells and chemicals.

Table 5. The ratios and concentrations of chemicals with media and cells required in each well according to Figure 3 after adding chemical.

\begin{tabular}{cccc}
\hline Code & Well number & Dilutions & Concentrations \\
\hline 1 & A1 and B1 & 1 & $4000 \mu \mathrm{M}$ \\
3 & A2 and B2 & $1 / 2$ & $2000 \mu \mathrm{M}$ \\
4 & A3 and B3 & $1 / 2$ & $1000 \mu \mathrm{M}$ \\
5 & A4 and B4 & $1 / 5$ & $200 \mu \mathrm{M}$ \\
6 & A5 and B5 & $1 / 2$ & $100 \mu \mathrm{M}$ \\
7 & A6 and B6 & $1 / 2$ & $50 \mu \mathrm{M}$ \\
8 & C1 and D1 & $1 / 2$ & $25 \mu \mathrm{M}$ \\
9 & C2 and D2 & $1 / 2$ & $12.5 \mu \mathrm{M}$ \\
10 & C3 and D3 & $1 / 10$ & $1.25 \mu \mathrm{M}$ \\
Empty & C4 and D4 & Positive control & Chemicals \\
Empty & C5 and D5 & Positive control & Chemicals \\
\hline & C6 and D6 & Negative control & Broth only \\
\hline
\end{tabular}




\subsection{Optical Density Analysis with Chemicals}

Using Gen5 software enter each plate individually to get the results showing the optical density through fluorescence assays of each well which evaluate the effect of each chemical and the response of the microorganism to it, input the results into excel sheets showing the concentrations of wells, names of microorganisms and chemicals used. Optical density is more preferred than ultraviolet spectrometry because the ultraviolet wave itself had an antibacterial activity which may interfere with the results of chemical effect on microorganism. Calculate the percentage of potency by the equation:

$\%$ of potency $=100-($ O.D of chemical/O.D of Blend $) * 100$

\subsection{Statistical Analysis for Microorganisms}

Using GraphPad prism input the data obtained from the excel sheet of gene 5 server then make non-linear regression to obtain graph showing the growth inhibition of each microorganism as well as calculation IC50, this curve can be fitted by dose response inhibition and then drawing log inhibitor by $\mu \mathrm{M}$ versus response to obtain variable slopes consist of four parameters and when you had more optical density you will need to reduce concentration and hence the lower IC is indication to the higher potency which means that the minimum dose of chemical is effective.

\section{Results}

\subsection{Optical Density Measurement (Table 6)}

Table 6. Optical density results for Asp. fumigatus according to readings multiplied by 20.

\begin{tabular}{ccc}
\hline & Reading & Optical density \\
\hline Blank & Zero & Zero \\
Asp. fumigatus & Zero & Zero \\
\hline
\end{tabular}

Chemical Preparation and Optical Density Analysis with Chemicals

It depends on the types and species of microorganisms as well as types and concentrations of chemicals, as shown in the following figures there are some microorganisms affected with chemicals in given concentration and others has not affected enough with the chemicals and need higher concentration. For optical densities means of results related to each concentration is calculated including positive and negative controls.

Asp. fumigatus

Blend

It is showing that it killed cells in concentrations from $4 \mathrm{mM}$ until the concentration of $1 \mathrm{mM}$ and after that it wasn't effective against cells (Figure 5, Table 7).

Cresol

It is showing that it killed cells in only concentration of $4 \mathrm{mM}$ after that it wasn't effective against cells (Figure 6, Table 8). 


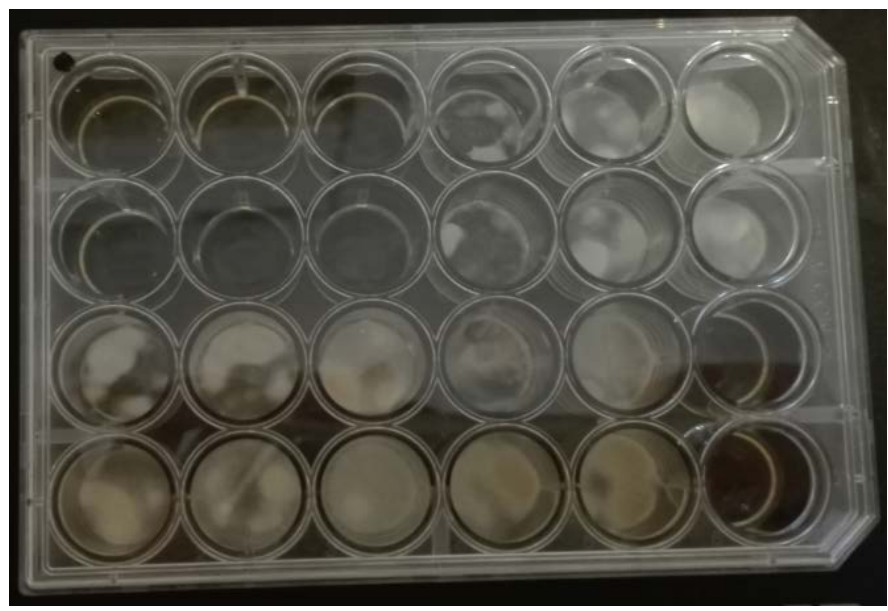

Figure 5. The effect of blend on Aspergillus fumigatus showing growth inhibition in concentrations from $4 \mathrm{mM}$ until $1 \mathrm{mM}$.

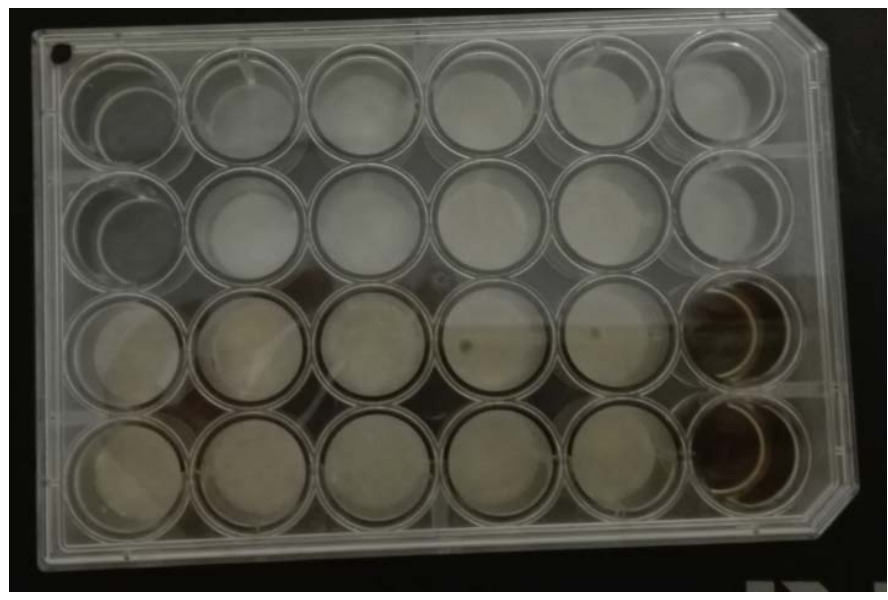

Figure 6. The effect of cresol on Aspergillus fumigatus showing growth inhibition in concentration of $4 \mathrm{mM}$.

Table 7. Values of optical density values between concentrations from $4 \mathrm{mM}$ until 1.25 $\mu \mathrm{M}$ as well as positive and negative controls related to the effect of blend on Asp. fumigatus.

\begin{tabular}{|c|c|c|c|c|c|}
\hline Concentration & & & & & Mean \\
\hline $4 \mathrm{mM}$ & 0.097 & 0.095 & & & 0.096 \\
\hline $2 \mathrm{mM}$ & 0.096 & 0.093 & & & 0.0945 \\
\hline $1 \mathrm{mM}$ & 0.092 & 0.089 & & & 0.0905 \\
\hline $200 \mu \mathrm{M}$ & 0.598 & 0.571 & & & 0.5845 \\
\hline $100 \mu \mathrm{M}$ & 0.992 & 2.214 & & & 1.603 \\
\hline $50 \mu \mathrm{M}$ & 1.612 & 1.288 & & & 1.45 \\
\hline $25 \mu \mathrm{M}$ & 0.685 & 1.504 & & & 1.0945 \\
\hline $12.5 \mu \mathrm{M}$ & 0.876 & 1.414 & & & 1.145 \\
\hline $1.25 \mu \mathrm{M}$ & 1.424 & 1.702 & & & 1.563 \\
\hline Positive controls & 1.858 & 1.904 & 1.634 & 1.444 & 1.71 \\
\hline Negative controls & 0.091 & 0.091 & & & 0.091 \\
\hline
\end{tabular}


Table 8. Values of optical density values between concentrations from $4 \mathrm{mM}$ until 1.25 $\mu \mathrm{M}$ as well as positive and negative controls related to the effect of cresol on Asp. fumigatus.

\begin{tabular}{|c|c|c|c|c|c|}
\hline Concentration & & & & & Mean \\
\hline $4 \mathrm{mM}$ & 0.487 & 0.582 & & & 0.5345 \\
\hline $2 \mathrm{mM}$ & 1.433 & 1.853 & & & 1.643 \\
\hline $1 \mathrm{mM}$ & 1.834 & 1.754 & & & 1.794 \\
\hline $200 \mu \mathrm{M}$ & 1.808 & 1.797 & & & 1.8025 \\
\hline $100 \mu \mathrm{M}$ & 1.622 & 1.882 & & & 1.752 \\
\hline $50 \mu \mathrm{M}$ & 1.7 & 1.68 & & & 1.69 \\
\hline $25 \mu \mathrm{M}$ & 1.832 & 1.706 & & & 1.769 \\
\hline $12.5 \mu \mathrm{M}$ & 1.759 & 1.744 & & & 1.7515 \\
\hline $1.25 \mu \mathrm{M}$ & 1.784 & 1.726 & & & 1.755 \\
\hline Positive controls & 1.847 & 1.759 & 1.259 & 1.906 & 1.69275 \\
\hline Negative controls & 0.097 & 0.093 & & & 0.095 \\
\hline
\end{tabular}

Indole

It is showing that it killed cells in concentrations from $4 \mathrm{mM}$ until the concentration of $1 \mathrm{mM}$ and after that it wasn't effective against cells (Figure 7, Table 9).

Skatole

It is showing that it killed cells in concentrations from $4 \mathrm{mM}$ until the concentration of $200 \mu \mathrm{M}$ and after that it wasn't effective against cells (Figure 8, Table 10).

\subsection{Statistical Analysis}

Making graphs illustrating microorganism growth inhibition by drawing a graph between OD 600 by $\mathrm{nm}$ and logarithm of chemicals by $\mu \mathrm{M}$ given to obtain the inhibitory concentration IC50 and R square which will lead to measure the potency according to the values of the previous tables.

Aspergillus fumigatus

Blend

The graph below shows OD 600 against log concentration of blend, as seen the IC50 equals approximately $196.7 \mu \mathrm{M}$ and R square is $0.7806 \mu \mathrm{M}$ (Figure 9).

Cresol

The graph below shows OD 600 against log concentration of cresol, as seen the IC50 equals approximately $2314 \mu \mathrm{M}$ and R square is $0.944 \mu \mathrm{M}$ (Figure 10).

Indole

The graph below shows OD 600 against log concentration of indole, as seen the IC50 average is between $102.7 \mu \mathrm{M}$ to $1036 \mu \mathrm{M}$ where IC50 equals approximately $326.3 \mu \mathrm{M}$ and $\mathrm{R}$ square is $0.9068 \mu \mathrm{M}$ (Figure 11). 
Skatole

The graph below shows OD 600 against log concentration of skatole, as seen the IC50 average is between $5.718 \mu \mathrm{M}$ to $2278 \mu \mathrm{M}$ where IC50 equals approximately $114.1 \mu \mathrm{M}$ and $\mathrm{R}$ square is $0.5944 \mu \mathrm{M}$ (Figure 12).

Table 9. Values of optical density values between concentrations from $4 \mathrm{mM}$ until 1.25 $\mu \mathrm{M}$ as well as positive and negative controls related to the effect of indole on Asp. fumigatus.

\begin{tabular}{|c|c|c|c|c|c|}
\hline \multicolumn{3}{|l|}{ Concentration } & & & \multirow{2}{*}{$\begin{array}{l}\text { Mean } \\
0.094\end{array}$} \\
\hline $4 \mathrm{mM}$ & 0.094 & 0.094 & & & \\
\hline $2 \mathrm{mM}$ & 0.09 & 0.09 & & & 0.09 \\
\hline $1 \mathrm{mM}$ & 0.09 & 0.092 & & & 0.091 \\
\hline $200 \mu \mathrm{M}$ & 0.772 & 2.079 & & & 1.4255 \\
\hline $100 \mu \mathrm{M}$ & 1.392 & 1.756 & & & 1.574 \\
\hline $50 \mu \mathrm{M}$ & 1.768 & 1.634 & & & 1.701 \\
\hline $25 \mu \mathrm{M}$ & 1.56 & 1.789 & & & 1.6745 \\
\hline $12.5 \mu \mathrm{M}$ & 1.63 & 1.747 & & & 1.6885 \\
\hline $1.25 \mu \mathrm{M}$ & 1.736 & 1.822 & & & 1.779 \\
\hline Positive controls & 1.981 & 1.805 & 1.893 & 1.75 & 1.85725 \\
\hline Negative controls & 0.09 & 0.091 & & & 0.0905 \\
\hline
\end{tabular}

Table 10. Values of optical density values between concentrations from $4 \mathrm{mM}$ until 1.25 $\mu \mathrm{M}$ as well as positive and negative controls related to the effect of skatole on Asp. fumigatus.

\begin{tabular}{|c|c|c|c|c|c|}
\hline Concentration & & & & & Mean \\
\hline $4 \mathrm{mM}$ & 0.173 & 0.181 & & & 0.177 \\
\hline $2 \mathrm{mM}$ & 0.094 & 0.092 & & & 0.093 \\
\hline $1 \mathrm{mM}$ & 0.652 & 0.09 & & & 0.371 \\
\hline $200 \mu \mathrm{M}$ & 0.406 & 0.1 & & & 0.253 \\
\hline $100 \mu \mathrm{M}$ & 0.794 & 1.079 & & & 0.9365 \\
\hline $50 \mu \mathrm{M}$ & 1.492 & 1.399 & & & 1.4455 \\
\hline $25 \mu \mathrm{M}$ & 0.229 & 1.555 & & & 0.892 \\
\hline $12.5 \mu \mathrm{M}$ & 0.39 & 1.413 & & & 0.9015 \\
\hline $1.25 \mu \mathrm{M}$ & 1.071 & 1.637 & & & 1.354 \\
\hline Positive controls & 1.741 & 1.837 & 1.648 & 1.848 & 1.7685 \\
\hline Negative controls & 0.091 & 0.092 & & & 0.0915 \\
\hline
\end{tabular}




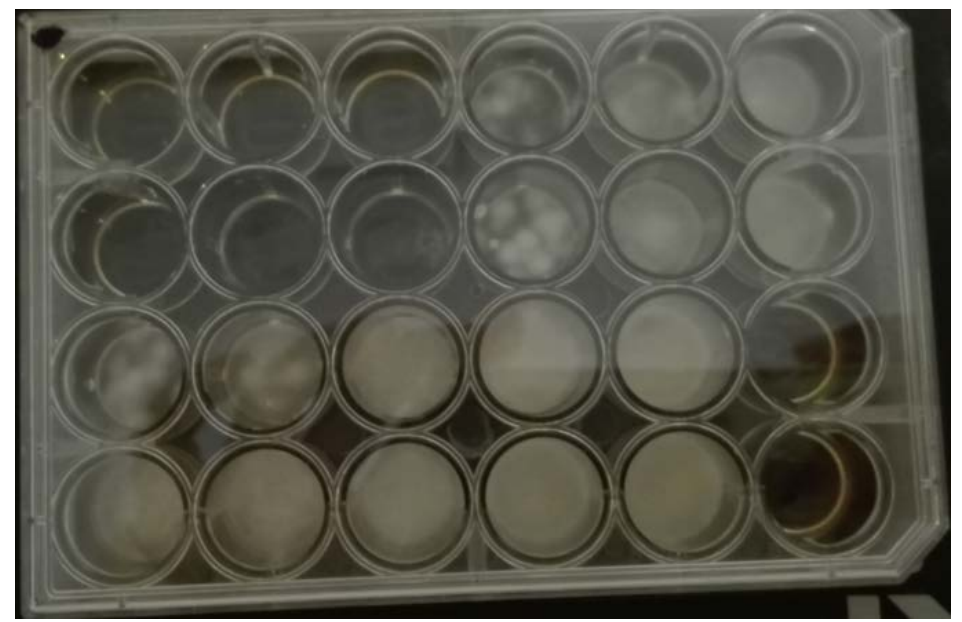

Figure 7. The effect of indole on Aspergillus fumigatus showing growth inhibition in concentrations from $4 \mathrm{mM}$ until $1 \mathrm{mM}$.

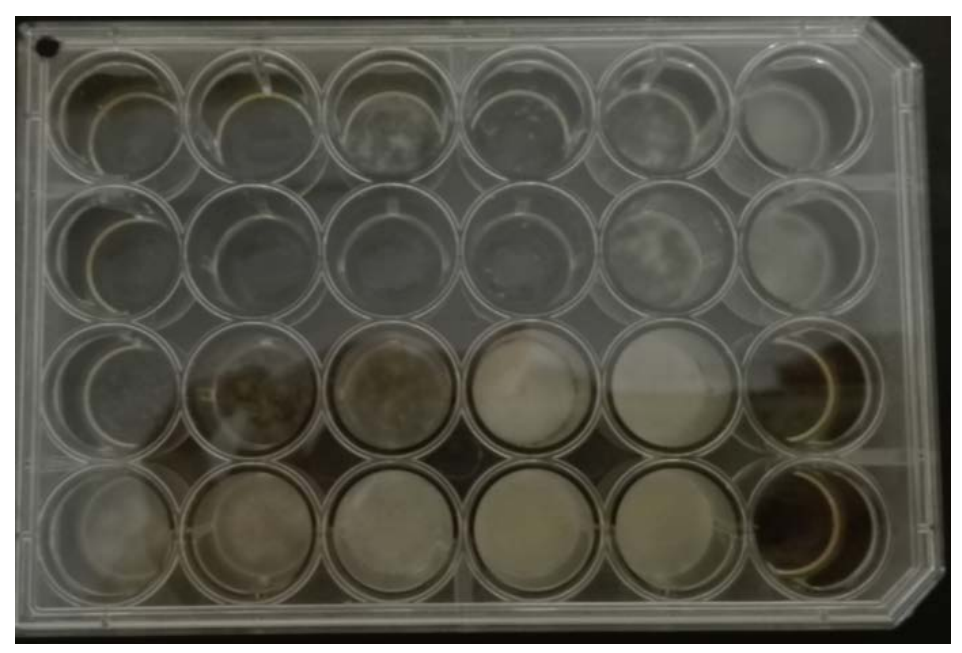

Figure 8. The effect of skatole on Aspergillus fumigatus showing growth inhibition in concentrations from $4 \mathrm{mM}$ until $200 \mu \mathrm{M}$.

\section{Asp.Fumigatus growth inhibition}

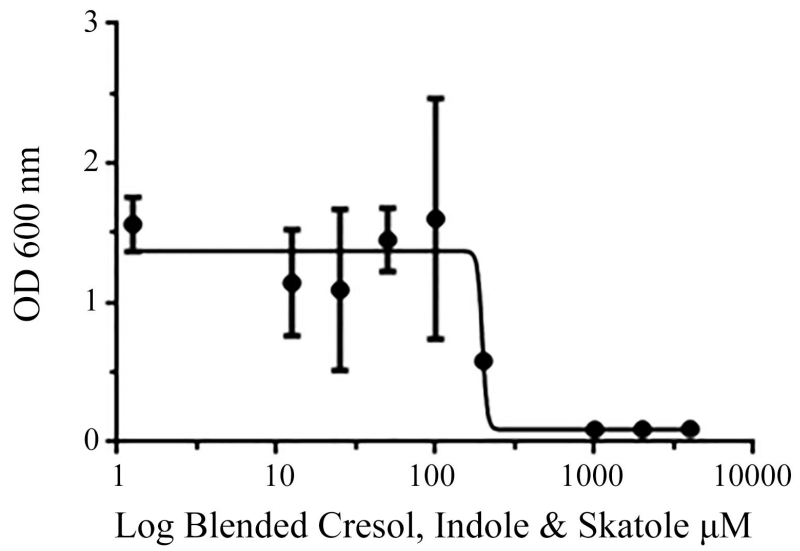

Figure 9. GraphPad shows optical density by Nano meter against log of blend related to Asp. fumigatus. 
Asp.Fumigatus growth inhibition

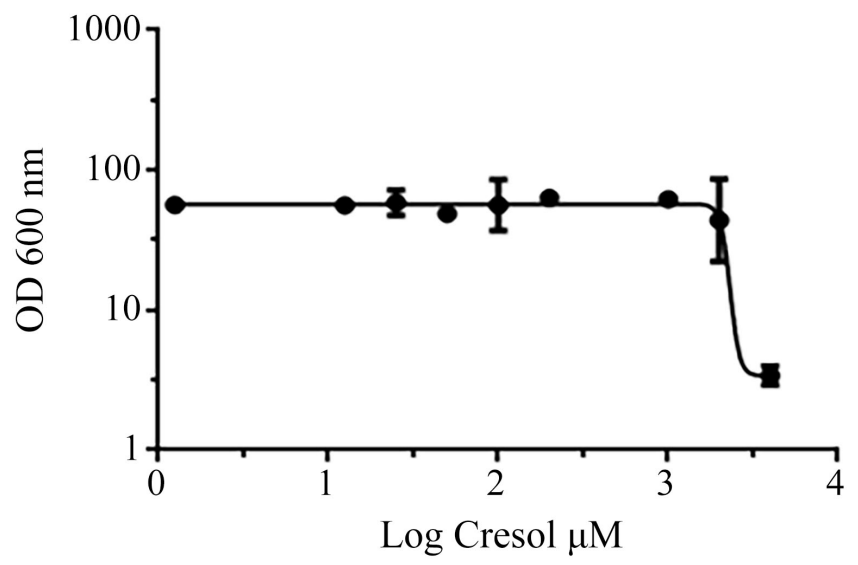

Figure 10. GraphPad shows optical density by Nano meter against log of cresol related to Asp. fumigatus.

Asp.Fumigatus growth inhibition

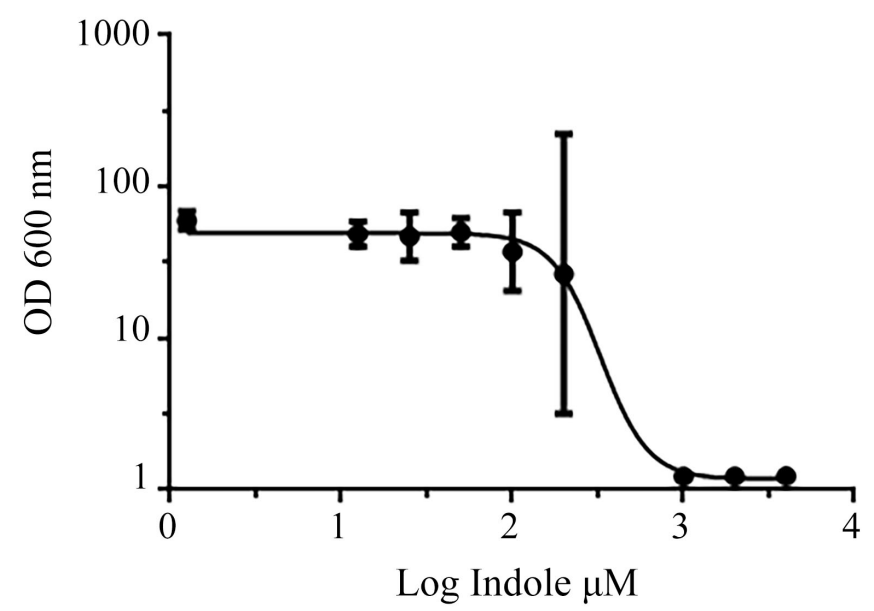

Figure 11. GraphPad shows optical density by Nano meter against $\log$ of indole related to Asp. fumigatus.

Asp.Fumigatus growth inhibition

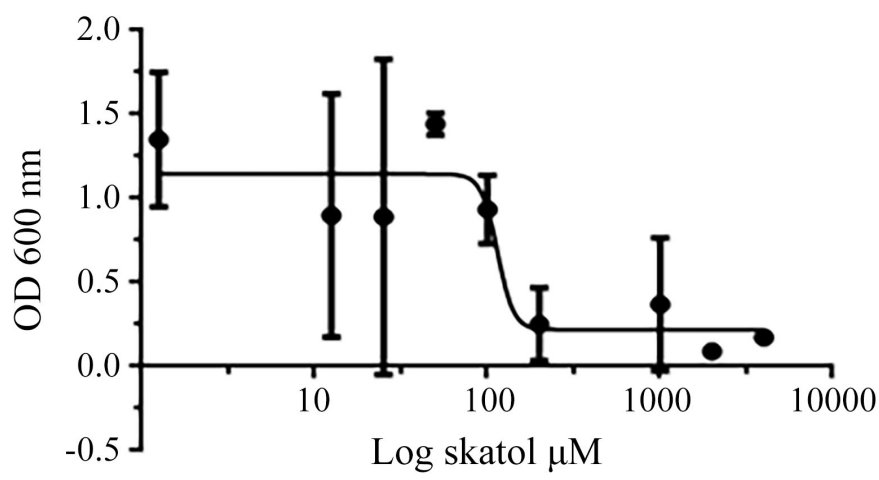

Figure 12. GraphPad shows optical density by Nano meter against log of skatole related to Asp. fumigatus. 


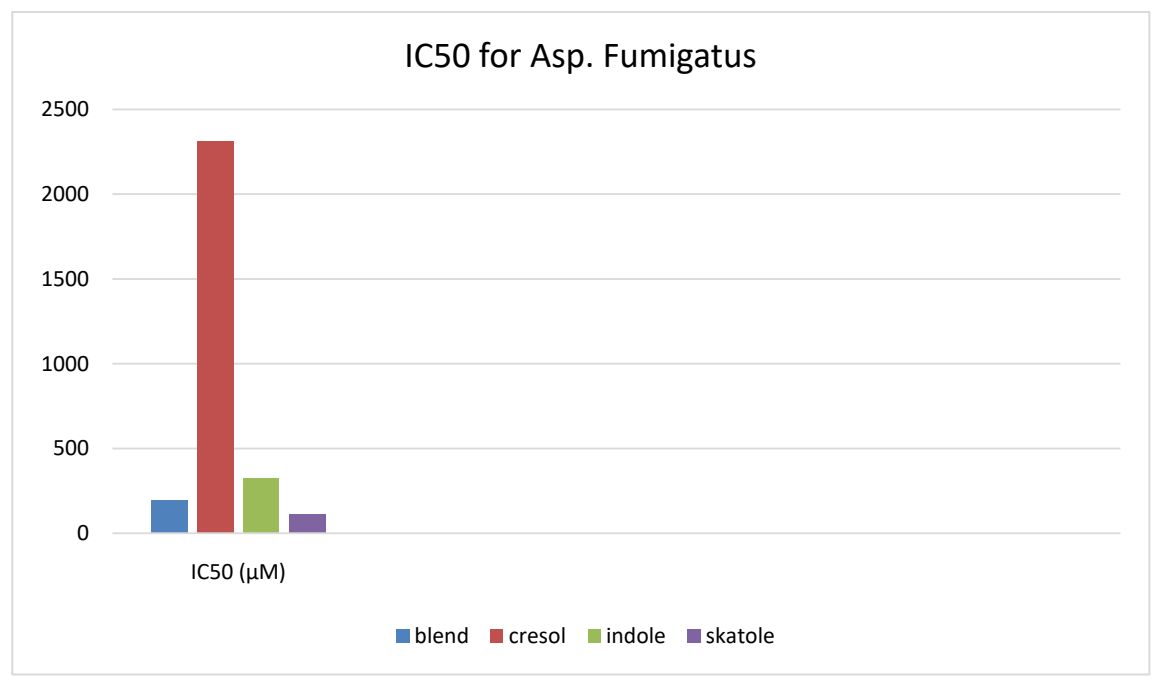

Figure 13. Chart showing IC50 for Asp. fumigatus in presence if indole, methyl indole, skatole and blend.

\section{Discussion}

Although it was hoped to extract chemicals from their animal sources as it has been difficult to be afforded so the chemicals had been bought instead, they were tangibly effective mostly against Asp. fumigatus. The optical density of fungus was out of the scale due to clumping so it didn't get the expected results as well as the turbidity is not an enough evidence that cells are grown so it can be used viable counts and serial dilution techniques.

The previous figures were showing that blend of indole, skatole and cresol has synergistic effect more than using each chemical alone and, at the same time, it plays a major role in diluting the toxic effect of p-cresol. In case of observation statistical analysis resulted from graph pad prism, although the IC50 is ambiguous in some graphs. However, this can help in determining the dose which is effective and economic in case this combination applied for medicinal uses.

Aspergillus fumigatus:

During its chemical preparation with blend it showed cell death at least concentration with blend $1 \mathrm{mM}, 4 \mathrm{mM}$ with cresol, $1 \mathrm{mM}$ with indole and $200 \mathrm{mM}$ with skatole, the IC50 of blend is $196.7 \mu \mathrm{M}$, IC50 of cresol is $2314 \mu \mathrm{M}$, IC50 of indole is $326.3 \mu \mathrm{M}$ and IC50 of skatole is $114.1 \mu \mathrm{M}$ which indicates the therapeutic potency of blend as well as skatole (Figure 13).

So, the blend is more synergistic in fungal infection and skatole is the most potent component in this combination.

\section{Conclusions}

The future work based on these results, His-tag cloning may be further done as some tags participates in the loss of activity of the peptide and optical density may be measured for measuring its inhibitory effects using $\mathrm{N}$ and $\mathrm{C}$ terminals.

Cloning and expression with yeasts can be done further with other protein 
peptides as lactoferrin and lactotransferrin which are found in the milk of many species of mammals and has antimicrobial activity. It can be extracted from milk of whales, camels and dolphins depending on their hydrophobicity and $\beta$-sheets which facilitates its penetration to the cell wall of microbes.

For chemicals, the blend of indole, skatole and cresol can be used for topical uses to protect the body against dermatological disturbances. This blend can be used topically as patches, ointments or creams, especially for some dermatologic disorders.

As well as using it for plants as onions to repel Aspergillus fumigatus which infects plants especially onions. The physical properties of these chemicals can be beneficial if they were used as spray to repel insects as flies and mosquitoes.

Further studies are needed to understand the overall properties of this combination and its effect against more microorganisms and its inhibitory effect to liver microsomal enzymes.

\section{Acknowledgements}

Very big thanks to Dr. Glen McCann: for his supervision, Dr. Neil Horley: who was the program leader, Dr. Noha Gamal: for revising this manuscript and her orientations, Prof. Dr. Randolph Aroo: for his hard work and discussion of this research, and Mr. Smith: the lab technician of Portland laboratory for his cooperative work.

\section{Conflicts of Interest}

The authors declare no conflicts of interest regarding the publication of this paper.

\section{References}

[1] Robert, E.W.H. and Monisha, G.S. (1988) The Role of Antimicrobial Peptides in Animal Defenses. Department of Microbiology and Immunology, University of British Columbia, Vancouver, BC, Canada, 1-2.

[2] Hancock, R.E.W. and Lehrer, R. (1998) Cationic Peptides: A New Source of Antibiotics. Trends Biotechnol, 16, 82-88. https://doi.org/10.1016/S0167-7799(97)01156-6

[3] Hetru, C., Hoffmann, D. and Bulet, P. (1998) In: Brey, P.T. and Hultmark, D., Eds., Molecular Mechanisms of Immune Responses in Insects, Chapman \& Hall, London, 40-66.

[4] Insect Antimicrobial Peptides OPM (2017) Orientations of Proteins in Membranes Database (OPM).

[5] Amphibian Antimicrobial Peptides (2017) Orientations of Proteins in Membranes Database (OPM).

[6] Yang, M., Zhang, C., Zhang, X., Zhang, M.Z., Rottinghaus, G.E. and Zhang, S. (2016) Structure-Function Analysis of Avian $\beta$-Defensin- 6 and $\beta$-Defensin-12: Role of Charge and Disulfide Bridges. BMC Microbiology, 16, Article No. 210. https://doi.org/10.1186/s12866-016-0828-y

[7] Niedermaier, H. (2012) Synthetic Mimics of Antimicrobial Peptides: A New Wave 
of Antibiotics. Department of Chemistry, University of Georgia.

[8] Kohn, E.M., Shirley, D.J., Arotsky, L., Picciano, A.M., Ridgway, Z., Urban, M.W., Carone, B.R. and Caputo, G.A. (2018) Role of Cationic Side Chains in the Antimicrobial Activity of C18G. Molecules, 23, 329.

https://doi.org/10.3390/molecules23020329

[9] Rzedzicki, J. and Stępień-Pyśniak, D. (2009) Antimicrobial Defence Mechanisms of Chicken Eggs and Possibilities for Their Use in Protecting Human and Animal Health. Division of Avian Diseases, Institute of Biological Bases of Animal Diseases, University of Life Sciences in Lublin, Lublin, Poland, Annales Universitatis Mariae Curie-Skłodowska. Sectio DD, Medicina Veterinaria, 64, 1-8.

[10] Manuel, M.-V., Aránzazu, P., Juan, M.P.-S., Lourdes, S., Samir, A., Magdalena, R.-R. and Juan, J.S. (2009) Antimicrobial Chemicals in Hoopoe Preen Secretions Are Produced by Symbiotic Bacteria. Proceedings of the Royal Society, 277, 123-130.

[11] Willam, F.W. and Paul, J.W. (2002) The Scent of the Reticulated Giraffe (Giraffa camelopardalis reticulata). Biochemical Systematics and Ecology, 30, 913-917. https://doi.org/10.1016/S0305-1978(02)00037-6

[12] Dagg, A.I., and Foster, J.B. (1976) The Giraffe: Its Biology, Behavior and Ecology. Van Nostrand Reinhold Co., New York.

[13] Cumming, R.G. (1870) The Lion Hunter of South Africa. 6th Edition, John Murray, London.

[14] Baldwin, W.G. (1894) African Hunting and Adventure from Natal to the Zambesi. Richard Bentley and Son, London.

[15] Fitzsimons, F.W. (1920) The Natural History of South Africa. Volume 3, Longmans, Green, London. https://doi.org/10.5962/bhl.title.54692

[16] Poucher, W.A. (1974) Chemotropism of Mosquitoes. In: Perfumes, Cosmetics and Soaps. Seventh Edition, Chapman and Hall, London.

[17] Kubo, I., Muroi, H. and Himejima, M. (1992) Antimicrobial Activity of Green Tea Flavor Components and Their Combination Effects. Journal of Agricultural and Food Chemistry, 40, 245-248. https://doi.org/10.1021/jf00014a015

[18] Kubo, A., Lunde, C.S. and Kubo, I. (1995) Antimicrobial Activity of the Olive Oil Flavor Compounds. Journal of Agricultural and Food Chemistry, 43, 1629-1633. https://doi.org/10.1021/jf00054a040

[19] Garg, A.P. and Mueller, J. (1993) Fungitoxicity of Fatty Acids against Dermatophytes. Mycoses, 36, 51-63.

[20] Morris, J.A., Khettry, A. and Seitz, E.W. (1979) Antimicrobial Activity of Aroma Chemicals and Essential Oils. Journal of the American Oil Chemists' Society, 56, 595-603. https://doi.org/10.1007/BF02660245

[21] Inouye, S., Goi, H., Miyauchi, K., Muraki, S., Ogihara, M. and Iwanami, Y. (1983) Inhibitory Effect of Volatile Constituents of Plants on the Proliferation of Bacteria: Antibacterial Activity of Plant Volatiles. Bokin Bobai, 11, 609-615.

[22] Kabara, J.J., Swieczkowski, D.M., Conley, A.J. and Truant, J.P. (1972) Fatty Acids and Derivatives as Antimicrobial Agents. Antimicrobial Agents and Chemotherapy, 2, 23-28. https://doi.org/10.1128/AAC.2.1.23

[23] Hogan, J.S., Pankey, J.W. and Duthie, A.H. (1987) Growth Inhibition of Mastitis Pathogens by Long-Chain Fatty Acids. Journal of Dairy Science, 70, 927-934. https://doi.org/10.3168/jds.S0022-0302(87)80096-6

[24] Fang, W and Latge, J.-P. (2018) Microbe Profile: Aspergillus fumigatus: A Sapro- 
trophic and Opportunistic Fungal Pathogen. Microbiology, 164, 1009-1011. https://doi.org/10.1099/mic.0.000651

[25] Waugh, R.J. and Bowie, J.H. (1997) Antimicrobial Peptides. Wiley, Chichester, 197-223.

[26] Ericksen, B., Wu, Z., Lu, W. and Lehrer, R.I. (2005) Antibacterial Activity and Specificity of the Six Human Alpha-Defensins. Antimicrobial Agents and Chemotherapy, 49, 269-275. https://doi.org/10.1128/AAC.49.1.269-275.2005

[27] Zasloff, M. (2002) Antimicrobial Peptides of Multicellular Organisms. Nature, 415, 389-395. https://doi.org/10.1038/415389a

[28] Russell, J.P., Diamond, G., Tarver, A.P., Scanlin, T.F. and Bevins, C.L. (1996) Coordinate Induction of Two Antibiotic Genes in Tracheal Epithelial Cells Exposed to the Inflammatory Mediators Lipopolysaccharide and Tumor Necrosis Factor Alpha. Infection and Immunity, 64, 1565-1568. https://doi.org/10.1128/iai.64.5.1565-1568.1996

[29] Diamond, G., Beckloff, N. and Ryan, L.K. (2008) Host Defense Peptides in the Oral Cavity and the Lung: Similarities and Differences. Journal of Dental Research, 87, 915-927. https://doi.org/10.1177/154405910808701011

[30] Howell, M.D., Gallo, R.L., Boguniewicz, M., Jones, J.F., Wong, C., Streib, J.E., et al. (2006) Cytokine Milieu of Atopic Dermatitis Skin Subverts the Innate Immune Response to Vaccinia Virus. Immunity, 24, 341-348. https://doi.org/10.1016/j.immuni.2006.02.006

[31] Territo, M.C., Ganz, T., Selsted, M.E. and Lehrer, R. (1989) Monocyte-Chemotactic Activity of Defensins from Human Neutrophils. The Journal of Clinical Investigation, 84, 2017-2020. https://doi.org/10.1172/JCI114394

[32] Hill, C.P., Yee, J., Selsted, M.E. and Eisenberg, D. (1991) Crystal Structure of Defensin HNP-3, an Amphiphilic Dimer: Mechanisms of Membrane Permeabilization. Science, 251, 1481-1485. https://doi.org/10.1126/science.2006422

[33] Bechinger, B., Aisenbrey, C. and Bertani, P. (2004) The Alignment, Structure and Dynamics of Membrane-Associated Polypeptides by Solid-State NMR Spectroscopy. Biochimica et Biophysica Acta, 1666, 190-204. 